\title{
The problem of comparison in comparative regionalism
}

\author{
PHILIPPE DE LOMBAERDE, FREDRIK SÖDERBAUM, \\ LUK VAN LANGENHOVE AND FRANCIS BAERT*
}

\begin{abstract}
There is virtually no systematic debate on the fundamentals of comparative research in the study of international regionalism. The field of research is very fragmented and there is a lack of interaction between EU studies and regionalism in the rest of the world. There is also a lack of communication between scholars from various theoretical standpoints and research traditions. Related to these two divides is the tension between idiographic and nomothetic methodologies. The purpose of this article is to contribute to the largely neglected debate on how to conduct and address three interrelated problems: a conceptual, a theoretical and a methodological one. Our claim is that the future of comparative regionalism should be one where old divides are bridged. This requires a combination of conceptual rigor, theoretical eclecticism, and sounder empirical research methods.
\end{abstract}

Philippe De Lombaerde is Associate Director of the UNU Institute on Comparative Regional Integration Studies (UNU-CRIS) in Bruges. He recently edited: The EU and World Regionalism: The Makability of Regions in the 21st Century (with Michael Schulz, Ashgate, 2009); Aid for Trade. Global and Regional Perspectives (with Lakshmi Puri, Springer, 2009); Governing Regional Integration for Development. Monitoring Experiences, Methods and Prospects (with Antoni Estevadeordal and Kati Suominen, Ashgate, 2008); Del regionalismo latinoamericano a la integración interregional (with Shigeru Kochi and José Briceño Ruíz, Siglo XXI, 2008), and Regionalisation and Global Governance (with Andrew Cooper and Chris Hughes, Routledge, 2008).

Fredrik Söderbaum is Associate Professor and Deputy Director at the School of Global Studies (SGS) at the University of Gothenburg, and Associate Senior Research Fellow of the UNU Institute on Comparative Regional Integration Studies (UNU-CRIS). Recent work includes a special issue (with Rodrigo Tavares) of the journal African Security (2:2-3) on the role of African regional organisations in African security, The European Union and the Global South (edited with Patrik Stålgren, Lynne Rienner, 2010); Afro-regions. The Dynamics of Cross-border Micro-regionalism in Africa (edited with Ian Taylor, Nordic Africa Institute, 2008), and The Political Economy of Regionalism. The Case of Southern Africa (Palgrave, 2004).

Luk Van Langenhove is Director of the UNU Institute on Comparative Regional Integration Studies (UNU-CRIS) and Vice-President of the International Social Sciences Council of UNESCO. He represents UNU-CRIS in the EC Framework Programme 6 projects SSH Futures (on the future of the social sciences and humanities in Europe) and GARNET (on global governance, regionalisation and regulation: the role of the EU) and is academic

\footnotetext{
* The authors would like to thank Hélène Gandois, Sieglinde Gstöhl, Björn Hettne, Chloe Middleton and the anonymous reviewers for constructive comments on earlier drafts. We are also grateful for the comments received at the conference 'Comparative Regionalism: Europe and East Asia' held in Beijing in February 2008 as well as at the GARNET Third Annual Conference on Mapping Integration and Regionalism in a Global World in Bordeaux, September 2008.
} 
coordinator of the EC Framework Programme 7 project EU-GRASP (on the EU as a regional-global actor in peace and security). His recent work includes People and Societies: Rom Harré and Designing the Social Sciences (Routledge, 2010); World-Regional Social Policy and Global Governance (edited with Deacon Bob, Maria Cristina Macovei, and Nicola Yeates, Routledge, 2010), and Innovating the Social Sciences (Passagen Verlag, 2007).

Francis Baert is Project Researcher at the UNU Institute on Comparative Regional Integration Studies (UNU-CRIS). He is member of the academic coordination team of the EC Framework Programme 7 project EU-GRASP (on the EU as a regional-global actor in peace and security). He is also enrolled as doctoral candidate at the Centre for EU Studies at the Department of Political Science of Ghent University.

\section{Introduction}

Since the mid-1980s there has been an explosion of various forms of regionalism on a global scale. The widening and deepening of the EU is the most pervasive example, but regionalism is also made visible through the revitalisation or expansion of many other regional projects around the world. Today's regionalism is characterised by the involvement of almost all governments in the world, but it also involves a rich variety of non-state actors, resulting in multiplicities of formal and informal regional governance and regional networks in most issue areas. As such, regionalism is closely linked with the shifting nature of global politics and the intensification of globalisation.

The pluralism and multidimensionality of contemporary regionalism gives rise to a number of new puzzles and challenges for comparative politics. Knowledge has accumulated within the study of regionalism during the last two decades. This includes the institutional design of numerous regional organisations as well as the relationship between globalisation and regionalism. However, the challenges and weaknesses in the study of regionalism are, in our view, primarily related to the fragmented nature of this research field, in particular the weak debate around comparative analysis. Despite a growing number of specific comparisons of selected aspects of regionalism (especially concerning regional institutions and the role of power) in selected regions, there is no systematic debate relating to the fundamentals of comparison. We do not attempt a detailed empirical comparison of a set of pre-defined regions according to a fixed set of variables; the purpose of the article is instead to contribute to this much-needed and largely neglected discussion. We distinguish thereby three interrelated problems: a conceptual problem (what are we studying? how should we conceptualise the phenomenon?), a theoretical problem (which theoretical framework to use? to what extent can theories be transplanted to other contexts?), and a methodological problem (how to use and balance between qualitative and quantitative methods?).

\section{Early and recent debates on comparative regionalism ${ }^{1}$}

The research problématique that we touch upon is not different in nature compared to other specialisations in the social sciences. What justifies this article is the fact

${ }^{1}$ Parts of this section draw on Björn Hettne and Fredrik Söderbaum, 'The Future of Regionalism: Old Divides, New Frontiers', in Andrew F. Cooper, Christopher W. Hughes and Philippe 
that the role of comparison is underdeveloped in the field of regionalism compared to most other fields within the social sciences.

The early debate on regionalism in the 1960s and 1970s was always centred on the European integration process, and the European experience was in many ways treated as a single case, even if many neo-functionalists (which was the most influential school of thought) were also engaged in comparative research. Haas, Schmitter and Dell studied regional integration (or the lack of it) in Latin America. $^{2}$ Etzioni compared the United Arab Republic, the Federation of West Indies, the Nordic Association and the European Economic Community. ${ }^{3}$ Nye studied East Africa and conducted comparisons of the Arab League, the Organization of American States (OAS) and the Organization of African Unity (OAU). ${ }^{4}$ However, most scholars lost their interest in regionalism outside Europe due to the perceived lack of regional integration elsewhere.

Neo-functionalism came under critique by intergovermentalism. Haas responded to critics by labelling the study of regional integration 'pre-theory' (on the basis that there was no clear idea about dependent and independent variables), then referred to the field in terms of 'obsolescence', and ended up suggesting that the study of regional integration should cease to be a subject in its own right. ${ }^{5}$ Rather, it should be seen as an aspect of the study of interdependence. Nye also underwent the same shift of interest. In retrospect it would appear that the neo-functionalists expected too much too quickly. They underestimated the anti pluralist, centralist and nationalist orientations of their time, at the same time as the theory had relatively little regard for exogenous and extra-regional forces. ${ }^{6}$

In the real world, the 1970s was a period of 'Eurosclerosis' within the European Communities. Elsewhere, attempts to create regional organisations were failing and most of these organisations fell dormant. Nevertheless, the 1985 White Paper on the internal market and the Single European Act resulted in a new dynamic process of European integration. This was also the start of what has often been referred to as the 'new regionalism' on a global scale. Naturally, this attracted a lot of interest in the late 1980s and early 1990s. What was striking, though, was the lack of correspondence in this respect between economics and political science. To some observers regionalism was 'new', mainly in the sense that it represented a revival of protectionism or neo-mercantilism. ${ }^{7}$ But most observers highlighted the fact that closure of regions was not on the agenda, rather, the current regionalism was to

De Lombaerde (eds), Regionalisation and Global Governance. The Taming of Globalisation? (London: Routledge), pp. 61-79.

${ }^{2}$ Ernst B. Haas, and Phillipe C. Schmitter, 'Economics and Differential Patterns of Integration. Projections about Unity in Latin America', International Organization, 18:4 (1964), pp. 259-99; Philippe C. Schmitter, 'A Revised Theory of Regional Integration', International Organization, 24:4 (1970), pp. 836-68; Sidney S. Dell, A Latin American Common Market? (New York: Oxford University Press, 1966).

${ }^{3}$ Amitai Etzioni, Political Unification: A Comparative Study of Leaders and Forces (New York: Holt, Rinehart and Winston, 1965).

4 Joseph S. Nye Jr, 'Comparing Common Markets: A Revised Neo-Functionalist Model', International Organization, 24:4 (1970), pp. 796-835; Joseph S. Nye, Peace in Parts: Integration and Conflict in Regional Organization (Boston: Little, Brown and Company, 1971).

${ }^{5}$ Ernst B. Haas, 'The Obsolescence of Regional Integration Theory', Berkeley, CA: Institute of International Studies working paper (1975).

${ }^{6}$ Shaun Breslin and Richard Higgott, 'Studying Regions. Learning from the Old, Constructing the New', New Political Economy, 5:3 (2000), pp. 333-52.

7 Jagdish Bhagwati, The World Trading System at Risk (Princeton: Princeton University Press, 1993). 
be understood as 'open regionalism'. 8 In the field of international relations, the studies of this so-called 'new regionalism' considered new aspects, particularly those focused on conditions related to what increasingly came to be labelled globalisation. According to this type of scholarship there are many ways in which globalisation and regionalism interact and overlap, in contrast to the dichotomy between perceiving regionalism as a stumbling-block or a building-block. ${ }^{9}$

One of the prominent scholars of the recent debate, Björn Hettne, emphasises that regionalism needs to be understood both from an exogenous perspective (according to which regionalisation and globalisation are intertwined articulations of global transformation) and from an endogenous perspective (according to which regionalisation is shaped from within the region by a large number of different actors). ${ }^{10}$ As mentioned above, the exogenous perspective has primarily developed during the recent debate, whereas the endogenous perspective underlines the continuities with functionalist and neo-functionalist theorising about the integration of Europe, the role of agency and the long-term transformation of territorial identities. But in contrast to the time in which Haas and the early regional integration scholars were writing, today there are many regionalisms and thus a very different base for comparative studies. It is apparent that neither the ontology nor the epistemology has remained static. Indeed, current regionalism may be seen as a new political landscape in the making, characterised by an increasing set of actors (state and non-state) operating on the regional arena and across several interrelated dimensions (security, development, trade, environment, culture, and so on). As a result, the definition of the phenomena become central, and even more contested.

The multidimensionality and pluralism of the regional phenomenon, both in Europe and the rest of the world, has resulted in the proliferation of a large number of theories and approaches to regionalism. For example, Söderbaum and Shaw's edited collection Theories of New Regionalism draws attention to variants of institutionalism, security complex theory, and a variety of constructivist, critical and 'new regionalism' approaches, such as the world order approach (WOA), new regionalism approach (NRA) and region-building approach. ${ }^{11}$ Mansfield and Milner's The Political Economy of Regionalism highlights a variety of neo-realist and neo-liberal institutional theories, new trade theories and new institutionalism. ${ }^{12}$ Laursen's Comparative Regional Integration ${ }^{13}$ emphasises a variety of governmentalist, power, constructivist, neo-functionalist and historical institutionalist

${ }^{8}$ Kym Anderson, and Richard Blackhurst (eds), Regional Integration and the Global Trading System (Harvester: Wheatsheaf, 1993); Vincent Cable and David Henderson (eds), Trade Blocs? The Future of Regional Integration (London: Royal Institute of International Affairs, 1994).

9 Björn Hettne, Andras Inotai and Osvaldo Sunkel (eds) Globalism and the New Regionalism (Macmillan, 1999); Mary Farrell, Björn Hettne and Luk Van Langenhove (eds), The Global Politics of Regionalism. Theory and Practice. (London: Pluto Press, 2005); Andrew F. Cooper, Christopher W. Hughes and Philippe De Lombaerde (eds), Regionalisation and Global Governance. The Taming of Globalisation? (London: Routledge, 2008).

${ }^{10}$ Björn Hettne, 'The Europeanization of Europe: Endogenous and Exogenous Dimensions', Journal of European Integration, 24:4 (2002), pp. 325-40.

${ }^{11}$ Fredrik Söderbaum and Timothy M. Shaw (eds), Theories of New Regionalism. A Palgrave Reader (Basingstoke: Palgrave, 2003).

12 Edward D. Mansfield and Helen V. Milner (eds), The Political Economy of Regionalism (New York: Colombia University Press, 1997).

13 Finn Laursen (ed.), Comparative Regional Integration (Aldershot: Ashgate, 2005). 
perspectives, whereas Wiener and Diez is a coherent exposé of the richness of European Integration Theory, highlighting: federalism, neo-neofunctionalism, liberal intergovernmentalism, multi-level governance, policy networks, new institutionalisms, social constructivism, integration through law, discursive approaches and gender perspectives. ${ }^{14}$ With regard to theoretical innovation it is also important to highlight the leading role played by scholars such as Amitav Acharya and Peter Katzenstein. ${ }^{15}$ Their work on regionalism in Asia in particular has played a groundbreaking role. Not all work within the field of new regionalism is inherently comparative. One can only argue that since the late 1990s, and after a slow start dominated by single or parallel case studies, comparative analysis has now become one of the most important trends in the contemporary study of regionalism. ${ }^{16}$ But in spite of a growing concern for comparative (mainly empirical) research, there is less systematic debate regarding the more general conceptual, theoretical and methodological challenges we are facing.

\section{The conceptual problem}

One of the biggest obstacles facing students of comparative regionalism is the conceptual one. There is a wide range of definitions of region, regional integration, regionalism, regionalisation and related concepts in the academic literature. During the early debate about regional integration in the 1960s and 1970s a large amount of research capacity was invested in trying to define regions 'scientifically'. ${ }^{17} \mathrm{~A}$ plethora of opinions were advanced regarding what mutual (regional) interdependencies mattered the most (such as economic, political and social variables, or historical, cultural and ethnic bonds). Definitions are of course essential in comparative research, since the definition and choice of concepts, including the fundamental question of what is a case, will affect the ability to compare and ultimately to generalise. The definition of key variables, such as regional integration and regionalism/regionalisation is, of course, also important in order to facilitate academic debate. The attempts of the 1960s and 1970s unfortunately

${ }^{14}$ Antje Wiener and Thomas Diez (eds), European Integration Theory (Oxford, 2003).

15 Amitav Acharya, Constructing a Security Community in Southeast Asia: ASEAN and the Problem of Regional Order (London: Routledge, 2001); Amitav Acharya, 'How Ideas Spread: Whose Norms Matter? Norm Localization and Institutional Change in Asian Regionalism', International Organization, 58:2 (2004), pp. 239-75; Peter J. Katzenstein, A World of Regions: Asia and Europe in the American Imperium (Ithaca: Cornell University Press, 2005); also see 'Roundtable: Peter J. Katzenstein's Contributions to the Study of East Asian Regionalism', Journal of East Asian Studies, 7:3 (2007), pp. 359-412.

${ }^{16}$ Walter Mattli, The Logic of Regional Integration. Europe and Beyond (Cambridge: Cambridge University Press, 1999); Amitav Acharya and Alastair Ian Johnston (eds), Crafting Cooperation. Regional International Institutions in Comparative Perspective (Cambridge: Cambridge University Press, 2007); Francesco Duina, The Social Construction of Free Trade. The EU, NAFTA, and Mercosur (Princeton: Princeton University Press, 2005); Mary Farrell, Björn Hettne and Luk Van Langenhove (eds), The Global Politics of Regionalism. Theory and Practice (London: Pluto Press, 2005).

17 Bruce M. Russett, International Regions and the International System. A Study in Political Ecology (Chicago: Rand \& McNally \& Co., 1967); Louis J. Cantori and Steven L. Spiegel, 'International Regions. A Comparative to Five Subordinate Systems', International Studies Quarterly, 13:4 (1969), pp. 361-80; Louis J. Cantori and Steven L. Spiegel (eds), The International Politics of Regions. A Comparative Approach (Englewood Cliffs: Prentice-Hall, 1970). 
produced few clear results as 'region' is a polysemous concept. The fact that the definition of a region 'depends' on the research problem does not mean that defining a region is not possible. But as it is a 'container-concept' with multiple meanings, some conceptual analysis is needed. It also implies that when academics and policy makers communicate about regions (and related phenomena) across paradigmatic or disciplinary borders, concepts should not be taken for granted.

Historically, the concept of region has evolved primarily as a space between the national and the local within a particular state. These types of regions are referred to as sub-national regions or micro-regions. The concept of region can also refer to macro-regions (so-called world regions), which are larger territorial (as distinct from non-territorial) units or sub-systems, between the state level and the global system level. The macro-region has been the most common object of analysis in world politics, while micro-regions have more commonly been considered in the realm of the study of domestic politics and economics. In current international affairs, where distinctions between the domestic and the international are blurred, micro-regions have increasingly become cross-border in nature, precipitating an emerging debate about the relationship between macro-regionalism and microregionalism within the context of globalisation. ${ }^{18}$ This shows that regions are not a natural kind: the concept is used when referring to different phenomena such as the EU, North- Rhine-Westphalia or the Euregio. ${ }^{19}$ It makes sense to use the generic term of region in those cases as it emphasises that there is something in common. This communality becomes obvious when looking at the discursive context in which it is used. ${ }^{20}$ That context refers to matters of governance, of territory or identity. These matters are also important when referring to states. In other words, calling something a region is done because it emphasises that that geographical area with its attached social community and/or system is not a state while at the same time it may have some statehood properties. As such one may say that in principle every geographical area in the world (with its social system) that is not a state may be considered as a region if to some extent statehood properties can be attributed to it. So, regions may be defined as what they are not: they are not sovereign states. But they have some resemblance of states. If one agrees that the common aspect of all regions is that the concept is used as a discursive tool to differentiate them from states, it becomes possible to define in a more precise way then what makes up a region. This can be done by referring to the concept of regionhood: which distinguishes a region from a non-region. ${ }^{21}$

A classical definition of a macro-region is, for example, Nye's: 'a limited number of states linked together by a geographical relationship and by a degree of

${ }^{18}$ See Markus Perkmann and Ngai-Ling Sum (eds), Globalization, Regionalization and the Building of Cross-Border Regions (Basingstoke: Palgrave, 2002); Fredrik Söderbaum and Ian Taylor, Regionalism and Uneven Development in Southern Africa. The Case of the Maputo Development Corridor (Aldershot: Ashgate, 2003).

19 Social scientist should re-examine the spatial assumptions that are taken for granted. A good starting-point for this debate is the overview of metageographical constructs as East, West, Europe, North, South, etc. done by Lewis and Wigen. Martin W. Lewis and Kären E. Wigen, 'The Myth of Continents. A Critique of Metageography' (Berkeley, Los Angeles and London: University of California Press, 1997).

${ }^{20}$ Nikki Slocum and Luk Van Langenhove, 'The Meaning of Regional Integration. Introducing Positioning Theory in Regional Integration Studies', Journal of European Integration, 26:3 (2004), pp. 227-52.

21 Luk Van Langenhove, 'Theorising Regionhood', UNU/CRIS e-Working Papers (2003), nr. 1. 
mutual interdependence'. ${ }^{22}$ The meaning of a number of geographically contiguous states is rather obvious, but Nye recognised that the degree of interdependence could vary between different fields. With this definition as a point of departure, Nye could then distinguish between political integration (the formation of a transnational political system), economic integration (the formation of a transnational economy) and social integration (the formation of a transnational society). ${ }^{23}$

The study of regional cooperation and regional integration has strongly emphasised sovereignty-centred definitions of regions and states as actors, or political unification within formal and macro-regional organisations (although neo-functionalist, institutionalist and especially transactionalist approaches certainly consider the underlying social fabric of non-state actors and interest groups). ${ }^{24}$ The majority of studies in the research field of comparative regionalism continue to focus on the policies of formal (even formalistic) regionalism as a state-led project (especially regional organisation) in contradistinction to the processes of regionalisation and the processes of region-building. ${ }^{25}$ Even though we believe that regional organisations ought to be compared, there are at least two additional circumstances which should guide design and conceptualisation: (i) all regional organisations may not be equally comparable, and (ii) the phenomenon of regionalism is much more comprehensive than what is captured by regional organisation left alone.

A rather recent tendency in the study of regionalism is the additional emphasis placed upon 'soft', de facto or informal regionalism/regionalisation, acknowledging the fact that a rich variety of non-state actors have begun to operate within as well as beyond state-led institutional frameworks. For instance, business interests and multinationals not only operate on the global level, but also tend to create regionalised patterns of economic activity, which may or may not affect inter-state frameworks. ${ }^{26}$ Similarly, civil society is often neglected in the study of regionalism, despite the fact that its impact is increasing, as evident in the transnational activist networks and processes of civil society regionalisation emerging around the world. ${ }^{27}$ According to Breslin et al. the distinction between formal and informal

22 Joseph S. Nye, Peace in Parts. Integration and Conflict in Regional Organization (Boston: Little, Brown and Company, 1971), p. vii.

${ }^{23}$ Ibid., pp. 26-7.

24 'Regional cooperation' can be defined as an open-ended process, whereby individual states (or possibly other actors) within a given geographical area act together for mutual benefit, and in order to solve common tasks, in certain fields, such as infrastructure, water and energy, notwithstanding conflicting interests in other fields of activity. 'Regional integration' refers to a deeper process whereby the previously autonomous units are merged into a whole.

25 'Regionalism' represents the policy and project, whereby mostly state actors cooperate and coordinate strategy within a particular region or as a type of world order. It is usually associated with a formal programme, and often leads to institution-building. 'Regionalisation' refers to the process of cooperation, integration, and cohesion creating a regional space (issue-specific or general). Andrew Hurrell makes a more nuanced distinction between five different categories of regionalism: (1) social and economic regionalisation; (2) regional awareness and identity; (3) regional inter-state cooperation; (4) state-promoted regional integration, and (5) regional cohesion. Andrew Hurrell, 'Regionalism in Theoretical Perspective', in Louise Fawcett and Andrew Hurrell (ed.), Regionalism in World Politics (Oxford: Oxford University Press, 1995), pp. 39-45.

${ }^{26}$ Alan M. Rugman, 'Regional Multinationals and the Myth of Globalisation', in Andrew F. Cooper, Christopher W. Hughes and Philippe De Lombaerde (eds), Regionalisation and Global Governance. The Taming of Globalisation (Abingdon and New York: Routledge, 2008), pp. 99-117.

27 Amitav Acharya, 'Democratization and the Prospects for Participatory Regionalism in Southeast Asia', Third World Quarterly, 24:2 (2003), pp. 375-90; Alex Warleigh, 'Europeanizing Civil Society. 
regionalism helps to 'break out of the teleological shackles of the first wave and may help us to move our focus to different types of regional response [and] to more issue-specific questions'. ${ }^{28}$ Another benefit is the increase in the number of cases to examine, even if this also makes it much more important to discuss the extent to which these cases are comparable or not.

The large majority of studies in the field of comparative regionalism have conventionally been concerned with macro-regions rather than micro-regions. This has, at least in our view, led to an under-emphasis of the heterogeneity and pluralism of regions, regionalisms, as well as micro-issues 'on the ground'. ${ }^{29}$ There are many valuable insights to be drawn from various so-called micro-level processes, such as growth triangles and export processing zones (EPZ) in East and Southeast Asia, old and more recent corridors in Southern Africa, maquiladoras along the US-Mexico border, as well as the Euroregions in Europe. ${ }^{30}$ Such micro-level forms of regionalism may sometimes be less formal/inter-state than the formal macro-regions; they may be more reflective of private sector interests than those of either states or civil societies. However, given that regions are constructed both by state and non-state actors and state boundaries are becoming more fluid, then it also becomes more difficult to uphold old distinctions between microregions and macro-regions. In addition, one should not neglect that both microand macro-regions come in different sizes. As such, a macro-region (for example, Benelux) can be smaller than a micro-region (for instance a Chinese province), in terms of population, economic weight or some other measure. Comparative work that covers micro-regions and macro-regions may sometime require open-ended definitions. At other times, especially more restrictive definitions can and should be used (see below).

Now, the view that regions should not be taken as given a priori is particularly emphasised in constructivist and reflectivist/post-structuralist scholarship. It goes without saying that the mainstream conceptualisation, whereby regions are taken largely as pre-defined, differs greatly from a view that considers regions as social constructions. In representing the latter standpoint, Jessop argues that 'rather than seek an elusive objective [...] criterion for defining a region, one should treat regions as emergent, socially constituted phenomena. ${ }^{31}$ From such a perspective, all regions are socially constructed and hence politically contested. Emphasis is placed on how political actors perceive and interpret the idea of a region and

NGOs as Agents of Political Socialization', Journal of Common Market Studies, 39:4 (2001), pp. 619-39; Fredrik Söderbaum, 'Regionalisation and Civil Society. The Case of Southern Africa', New Political Economy, 12:3 (2007), pp. 319-37.

${ }^{28}$ Shaun Breslin, Richard Higgott and Ben Rosamond, 'Regions in Comparative Perspective', in Shaun Breslin, Christopher W. Hughes, Nicola Philips and Ben Rosamond (eds), New Regionalisms in the Global Political Economy (London: Routledge, 2002), p. 13.

${ }^{29}$ Fredrik Söderbaum and Ian Taylor (eds), Afro-Regions: The Dynamics of Cross-Border MicroRegionalism in Africa (Uppsala: Nordic Africa Institute, 2008).

${ }^{30}$ Markus Perkmann and Ngai-Ling Sum (eds), Globalization, Regionalization and the Building of Cross-Border Regions (Basingstoke: Palgrave, 2002); Fredrik Söderbaum and Ian Taylor, Regionalism and Uneven Development in Southern Africa. The Case of the Maputo Development Corridor (Aldershot: Ashgate, 2003).

31 Robert Jessop, 'The Political Economy of Scale and the Construction of Cross-Border Regions', in Fredrik Söderbaum and Timothy M. Shaw (eds), Theories of New Regionalism. A Palgrave Reader (Basingstoke: Palgrave, 2003), p. 183. Also see Peter J. Katzenstein, The Culture of National Security. Norms and Identity in World Politics (New York: Columbia University Press, 1996). 
notions of 'regionness'. ${ }^{32}$ From this point of view, the puzzle is to understand and explain the process through which regions are coming into existence and are being consolidated - their 'becoming' so to speak - rather than to explain a particular set of activities and flows within a pre-given, region or regional framework. Hence, in this kind of analysis, regional inter-state organisations are seen as a second order phenomenon, compared to the processes that underlie processes of regionalisation and region-building. Regions are constructed and reconstructed through social practices and in discourse. Thus, calling a certain geographical area a region needs to be seen as a discursive tool that is used to obtain certain goals. It is therefore possible that various regional spaces overlap in territorial terms, and as Neumann eloquently points out, 'multiple alien interpretations of the region struggle, clash, deconstruct, and displace one another'. ${ }^{33}$

The tendency to see a pluralism of regional scales and regional actors has lead to an increasing pluralism of regional definitions, scales and spaces - mega-, macro-, meso-, sub- and micro-regions - all of which are intertwined with globalisation and national spaces. At first sight, this pluralistic perspective appears to be somewhat difficult to reconcile with hermetically sealed and pre-defined regions. It may also appear that the constructivist and post-structuralist understandings of regions pose certain challenges for systematic comparison. However, we believe there need be no conflict. Increased communication between different theoretical standpoints requires more precise definitions and increased emphasis on explaining what, exactly, is 'regional' and what is not. This can best be done by looking at the different discursive contexts (such as security-related discourse or economic discourse), in which references to being or becoming a region occur. Furthermore, in this process it becomes more important to tackle the question of comparability between regions, which requires explicit reflection over when and why, for instance, regional organisations can and should be compared.

A related aspect of comparability is linked to the process characteristics of the regional phenomenon. Regionalisation can be thought of as a long-term process of social transformation, in which 'phases' can be distinguished. These phases can be defined, in turn, in terms of a particular degree of regionness. ${ }^{34}$ The identification of 'comparable' cases should take this into account. Rather than comparing different regionalisation processes in the same historical moment or lapse of time, it might make sense to compare the cases in comparable logical moments or lapses of time. ${ }^{35}$

32 Björn Hettne and Fredrik Söderbaum, 'Theorising the Rise of Regionness', New Political Economy, 5:3 (2000), pp. 457-74; Björn Hettne, 'Beyond the New Regionalism', New Political Economy, 10:4 (2005), p. 548 .

33 Iver B. Neumann, The Region-building Approach, in Söderbaum and Shaw, Theories of New Regionalism (Palgrave Macmillan, 2003).

${ }^{34}$ Björn Hettne, and Fredrik Söderbaum, 'Theorising the Rise of Regionness', New Political Economy, 5:3 (2000), pp. 457-74.

35 Dorrucci et al., for example, compare the conditions for monetary integration in the EC in the 1960 s and 1970s with the corresponding conditions for Mercosur in the 1990s. Several other researchers have followed similar approaches. Ettore Dorrucci, Stefano Firpo, Marcel Fratzscher and Francesco Paolo Mongelli, 'European Integration: What lessons for other regions? The case of Latin America', ECB Working Paper (2002), nr. 185; Ettore Dorrucci, Stefano Firpo, Marcel Fratzscher and Francesco Paolo Mongelli, 'The Link between Institutional and Economic Integration: Insights for Latin America from the European Experience', Open Economies Review, $15: 3$ (2004), pp. 239-60. 
Indeed, conceptual pluralism is not necessarily problematic even from a comparativist viewpoint. Pluralism does not equal anarchy; for academic work to be productive, minimal common understandings are necessary. A possible way forward is avoiding spending too much energy on the precise wordings of the definitions, but rather, focussing on the essential characteristics of the regional phenomenon, thereby distinguishing it from non-regions. One possibility is the notion of 'regionhood', which sees regions as non-sovereign governance systems with (partial) statehood properties, and macro-regions as non-sovereign governance systems between the national and global level. ${ }^{36}$ This can be broad enough to allow for comparative research. One could argue that by using the neo-logism regionhood, interaction with contemporary mainstream scholars of EU Studies is at least possible.

However, this is of course only one possibility. There are many other possibilities. For example, the essential characteristic could refer to the existence of a common identity or social recognition. Alternatively it could refer to the existence of minimum levels of (regional) interdependence, as found in the definitions of a security community, ${ }^{37}$ a security complex, ${ }^{38}$ regional orders approach, ${ }^{39}$ regional peace and security cluster ${ }^{40}$ or an optimum currency area (OCA) ${ }^{41}$ These definitions do not refer to sovereignty and so do not essentially rely on the absence of sovereignty at the regional level for their validity. In the definition of OCAs, scale comes before form.

The way forward is to distinguish classes of definitions that are characterised by a 'hard core' consisting of essential elements, rather than to engage in trench-wars over the specificities of particular definitions. These hard cores usually refer to internal characteristics: 'regionhood' (statehood properties without sovereignty), identity, institutionalisation, etc., or a combination of these. However, the hard core could also refer to external characteristics, for example: the capacity to interact with other regions and with the global governance level or the capacity to (economically or politically) influence other regions or the global economy or polity. Definitions referring essentially to external characteristics could be called 'exogenous' definitions, as compared to 'endogenous' ones.

It is important to understand the link between the conceptual problem and the problem of comparability in empirical research. If the link between national and regional governance and rule-making are considered essential characteristics of a macro-region, then it might be reasonable to compare the EU with SADC in order to study, for example, how national constitutional courts deal with regional rule-making. However, if the capacity to influence decision-making in the area of

${ }^{36}$ Luk Van Langenhove, 'Theorising Regionhood', UNU/CRIS e-Working Papers (2003), nr. 1.

${ }^{37}$ Karl W. Deutsch, et al., Political Community and the North Atlantic Area: International Organization in the Light of Historical Experience (Westport Conn.: Greenwood Press, 1957).

${ }^{38}$ Barry Buzan, People, States and Fear: An Agenda for International Security Studies in the Post-Cold War Era (New York and London: Harvester Wheatsheaf, 1991); Barry Buzan and Ole Waever, Regions and Powers. The Structure of International Security (Cambridge: Cambridge University Press, 2003).

${ }^{39}$ David A. Lake and Patrick M. Morgan, Regional Orders. Building Security in a New World (Pennsylvania: Pennsylvania University Press, 1997).

40 Rodrigo Tavares, 'Understanding Regional Peace and Security. A Framework for Analysis', Contemporary Politics, 14:2 (2008), pp. 107-27.

${ }^{41}$ Robert A. Mundell, 'A Theory of Optimum Currency Areas', American Economic Review, 51:4 (1961), pp. 509-17. 
global trade (for example, within the World Trade Organization) is considered an essential characteristic of a region (in the sense of a regional economic power), then it probably makes more sense to compare the EU with the US. In this way it can be seen that the identification of relevant comparators follows logically from the conceptualisation of the phenomenon and the research questions under study.

As explained below, the $n=1$ problem (referring to the comparability of the European case) has received a lot of attention in regionalism studies. Now, if we look at it from the conceptual angle it might emerge that it is not such a 'problem' after all. Let us explain this by using an analogy from comparative politics (or comparative economics) where national polities (or economies) are compared. If the general question is asked, whether the US is comparable with Pakistan then the answer necessarily is, 'it depends'. They both belong to the category of formally sovereign states, so in that respect they are comparable. Directly related issues such as how their constitutions are drafted, how political participation is taking place or how they vote in the UN General Assembly can be compared. But at the same time they are not good cases for comparison when it comes to comparing the functioning of federal systems, the priorities in space programmes, or the impact of monetary policies on the global economy, etc. Following on from this, the question whether the EU can be compared with SAARC is similar to the question whether the US is comparable to Pakistan. The answer is that it depends on the research question. Yet at the same time, they both belong to the broad category of macro-regions, if they are defined as non-sovereign governance systems involving territories and actors belonging to a few neighbouring states. From this perspective, the preoccupation with the $n=1$ problem seems to be exaggerated.

In concluding this section it can thus be argued that conceptual pluralism is inevitable. The definition and understanding of the region 'depends' firstly on the type of discourse, in which a certain geographical area is presented as a region, and secondly on the research questions that are being addressed. The implication hereof is that explicit treatment of underlying concepts is a necessity, especially when dealing with comparative and interdisciplinary work. In view of this, it is recommended to focus on the 'hard core' of the various categories of definitions and on the discursive contexts in which they are used. It should be understood that the choice of the definition (and therefore, the phenomenon to be studied) has implications for the identification of the relevant cases to be selected in comparative research.

\section{The theoretical problem: the dominant role of European integration theory}

As mentioned above, many theories have been proposed to explain the regionalisation process (and related phenomena). Suffice it to say that when the phenomena are defined with sufficient rigor (see above), it becomes apparent that most of the existing theories complement, rather than compete against one another. Indeed, most of the theories are not 'competing' in the sense that they try to 'explain' identical phenomena in different ways, but rather they tend to focus on different (related) aspects of the phenomena we are interested in (major historical events, spill-over mechanisms, cost/benefits of integration decisions, etc.). Consistent with 
conceptual pluralism and the multiplicity of research questions, theoretical eclecticism is thus a logical implication.

At the same time we observe that there is weak communication between different theoretical standpoints, especially between rationalists, constructivists and reflectivists. Comparison should therefore be seen as an opportunity for different theoretical standpoints to communicate, where explanatory and interpretative theory can debate and perhaps even influence one another.

In this section we will focus on a central problem of the theorisation of comparative regionalism, namely the 'euro-centric' bias of most regionalism theories and the tendency to use the European integration experience as a comparator for other regions. In one sense there is nothing unusual about Eurocentrism. In this light we agree with Lewis and Wigen in their account on Eurocentrism in geography: 'all geographical traditions are rooted in local concerns and ethnocentric conceits, and had China emerged as the hegemon of the modern world system, our metageographical concepts would surely reflect Sinocentrism'. ${ }^{42}$ Likewise, Western (male) viewpoints are standard in many disciplines. The problem is that understanding can become distorted, irrespective of which perspective dominates or shapes the paradigm from which all other views are judged.

In the study of regionalism there is an extremely strong bias in favour of European integration theory and practice. Even if regional specialists often consider their own region to be 'special' or even 'unique', these regionalisms are very often compared - implicitly or explicitly - against the backdrop of European integration theory and practice. The Eurocentric bias in comparative regionalism and related theory-building has been a problem for several decades. Even if many of the classical neo-functionalists were conscious of their own Eurocentrism, they searched above all for those 'background conditions', 'functional equivalents' and 'spill - over' effects that were derived from the study of Europe. As Breslin et al. point out, they 'used the European experience as a basis for the production of generalisations about the prospects for regional integration elsewhere' ${ }^{43}$ This resulted in difficulties in identifying comparable cases, or anything that corresponded to their definition of 'regional integration'. This gave rise to the $n=1$ dilemma, which is discussed in the next section.

The argument here is that the treatment of European integration as the primary case or 'model' of regional integration still dominates many of the more recent studies of regionalism and regional integration, which is an important part of 'the problem of comparison' within this research area. At least two broad attitudes towards comparative analysis within the field of regionalism are distinguishable, which revolve around two competing attitudes towards European integration theory (and practice). Both of these standpoints are obstacles to the development of a more genuine comparative regionalism. One strand of thinking tends to elevate

${ }^{42}$ Martin W. Lewis and Kären E. Wigen, The Myth of Continents. A Critique of Metageography (Los Angeles: University of California Press, 1997), p. 10. See for a discussion on the 'Western' dominance of IR theory: Ole Waever, 'The Sociology of a Not So International Discipline: American and European Developments in International Relations Author(s)', International Organization, 52:4 (1998), pp. 687-727; Arlene Tickner, 'Seeing IR Differently: Notes from the Third World', Millennium: Journal of International Studies, 32:2 (2003), pp. 295-324.

43 Shaun Breslin, Richard Higgott and Ben Rosamond, 'Regions in Comparative Perspective', in Shaun Breslin, Christopher W. Hughes, Nicola Philips and Ben Rosamond (eds), New Regionalisms in the Global Political Economy, (London: Routledge, 2002), p. 2. 
European integration theory and practice through comparative research, while the other is considerably less convinced of the advantages of comparative research and Europe-centred theories. The first perspective - especially variants of realist/ intergovernmental and liberal/institutional scholarship - strongly emphasises Europe-centred generalisations. This type of research has been dominated by a concern to explain variations from the 'standard' European case. Indeed, other modes of regionalism are, where they appear, characterised as loose and informal (such as Asia) or 'weak' (such as Africa), reflecting 'a teleological prejudice informed by the assumption that 'progress' in regional integration is defined in terms of EU-style institutionalition'. ${ }^{44}$ One reason for this bias lies in the ways the underlying assumptions and understandings about the nature of regionalism (which most often stem from a particular reading of European integration) influence perceptions about how regionalism in other parts of the world does (and should) look. In other words, Eurocentrism results in a false universalism. As Hurrell asserts, "the study of comparative regionalism has been hindered by so-called theories of regionalism which turn out to be little more than the translation of a particular set of European experiences into a more abstract theoretical language. ${ }^{45}$

Avoiding Europe-centeredness has been an ongoing issue in the study of regionalism among developing countries and for critical scholarship in the field of international relations. There are persuasive reasons for taking stock of cumulative research on regionalism in the developing world and for being cautious regarding EU-style institutionalisation inherent in most classical or mainstream perspectives or policies. Indeed, there have been a number of innovative efforts to develop a regional approach specifically aimed at the developing world. ${ }^{46}$ However even these perspectives often tend to mirror the Europe-centred view, thus celebrating the differences in theory and practice between regionalism in Europe and in the developing word. According to Warleigh and Rosamond this has even resulted in a caricature of European integration and/or of classical regional integration theory, giving rise to unnecessary fragmentation within the field. ${ }^{47}$

The barrier for achieving an integrated comparative analysis is not European integration experience or theory per se, but rather the dominance of certain constructions and models of European integration. Conversely, discussions about regionalism in Africa or Asia have often reduced the EC/EU to the community method or a common market, or a simple point of reference, or to a model/antimodel. Furthermore, many comparisons and generalisations, which depart from the European context, are skewed through a lack of sensitivity to comparing

44 Shaun Breslin, Richard Higgott and Ben Rosamond, 'Regions in Comparative Perspective', in Shaun Breslin, Christopher W. Hughes, Nicola Philips and Ben Rosamond (eds), New Regionalisms in the Global Political Economy (London: Routledge, 2002), p. 11.

45 Andrew Hurrell, 'The Regional Dimension of International Relations Theory', in Mary Farrell, Björn Hettne and Luk Van Langenhove (eds), The Global Politics of Regionalism. Theory and Practice (London: Pluto Press, 2005), p. 39.

46 Andrew W. Axline (ed.), The Political Economy of Regional Cooperation. Comparative Case Studies (London: Pinter Publishers, 1994); Marianne H.. Marchand, Morten Bøås and Timothy M. Shaw, 'New Regionalisms in the New Millennium', Third World Quarterly (special issue), 20:5 (1999), pp. 897-910; Daniel Bach (ed.), Regionalisation in Africa: Integration and Disintegration (Oxford: James Currey, 1999).

47 Alex Warleigh and Ben Rosamond, Theorising Regional Integration Comparatively. An Introduction, Paper presented at ECPR Joint Sessions of Workshops, Nicosia (25-30 April 2006). 
regions with different levels of development and holding unequal positions in the current world order.

A more advanced debate about comparative regionalism will not be reached through simply celebrating differences between European integration and regionalism in the rest of the world, but rather by going beyond dominant interpretations of European integration, and drawing more broadly upon alternative theories that draw attention to aspects of European integration that are more comparable to other regions. To neglect Europe is to miss the opportunity of taking advantage of the richness of the EU project and laboratory. The challenge for comparative regionalism is to both include and transcend European integration theory and practice. But this requires enhanced communication between various specialisations and theoretical standpoints. Finally, more attention should be paid to theories, concepts and ideas that have emerged outside Europe, for example, open regionalism, flying geese patterns and growth triangles in an Asian context, Pan-Africanism, development corridors and informal cross-border networks in an African context, Prebisch' views and pan-Americanism (Bolivarism) in a Latin American context. For comparative analysis, the extent to which their relevance transcends regional particularities should be explored.

\section{The problem of empirical methodology}

As in any social sciences endeavour, there are two broad approaches to the study of regions. The first is to study single cases with an emphasis on understanding the historical processes of the case. This is called idiographic research and is usually dominated by qualitative research approaches. ${ }^{48}$ The second approach is to study multiple cases with an emphasis on finding general explanations that account for all the phenomena studied. This is called nomothetic research and is characterised by quantitative research approaches. In comparative regionalism, the latter approach has been mostly utilised to study the economic impacts of regional trade agreements. In between stands the comparative case study method. In the following analysis both of these approaches will be briefly discussed and it will be argued that a combination is feasible and desirable in order to improve the quality of comparative work in this area. We will point to some of the weaknesses in current comparative empirical research on regionalism.

\section{The case-study method: $n=1$ or $n>1$ ?}

As mentioned in the previous section, the debate on comparative regionalism has been dominated by Europe as the primary case of regional integration. This 'Europe-centeredness' constitutes an obstacle not only to deepening and broadening the understanding of regionalisms outside the EU, but also to acquiring a

48 The idiographic/nomothetic division has its origins in psychology but can be applied to all other social sciences. See, Jonathan A. Smith, Rom Harré and Luk Van Langenhove, Rethinking Methods in Psychology (London: Sage, 1995). 
deepened understanding of the EU by increased comparative regionalism. One of the main problems is related to the perception of the EU as sui generis. Deriving from this so-called ' $n=1$ problem', there is a serious lack of communication and interaction between EU studies and regionalism in the rest of the world, although some recent attempts have begun to remedy this deficiency. ${ }^{49}$

Indeed, there has been a tendency within EU studies during the recent decade to consider the EU as a nascent, if unconventional, polity in its own right. This view holds that the EU should be studied as a political system rather than as a project of regional integration or regionalism, thereby downplaying the similarities between the EU and other regionalist projects. ${ }^{50}$ The corollary is that established tools of political science and comparative politics should be used in EU studies and that international studies and international relations are not equipped to deal with the complexity of the contemporary EU. According to Ben Rosamond, however, the parochialism inherent in this particular strand of EU studies has contributed little in deepening our understanding of the EU as a political system. ${ }^{51} \mathrm{He}$ argues instead that EU studies should return to the broader ambitions of the comparative and classical regional integration theory (especially neo-functionalism), at least to the extent of developing comparative conceptual and theoretical frameworks with more general application. ${ }^{52}$ As noted above, even if the basic concepts need to be adjusted and revised to fit the realities of contemporary regionalism and the context of globalisation, the rigor with which earlier theorists undertook comparative analysis may serve as inspiration for the development of a more genuinely comparative regionalism.

The (perceived) lack of comparable cases, combined with the complexity of the regional phenomenon, help to explain the preference for the single case study method. This tendency has been further strengthened by recent developments in social constructivist and new regionalist approaches to regionalisation. Many scholars tend to use specific contextual language to describe rather similar phenomena in different regions instead of applying general concepts and developing questions and hypotheses that can be transferred to cross-regional comparisons. In other words, there is a tension in the field of regionalism between regional

${ }^{49}$ Finn Laursen, Comparative Regional Integration. Theoretical Perspectives (Aldershot: Ashgate, 2003); Mario Telò (ed.), EU and New Regionalism. Regional Actors and Global Governance in a Post-Hegemonic Era (Aldershot: Ashgate, 2007); Alex Warleigh, 'In Defence of Intra-Disciplinarity. European Studies, the New Regionalism, and the Issue of Democratisation', Cambridge Review of International Affairs, 17:2 (2004), pp. 301-18; Alex Warleigh, 'Learning form Europe? EU Studies and the Re-thinking of International Relations', European Journal of International Relations, 12:1 (2006), pp. 31-51.

50 Simon Hix, 'The Study of the European Community: The Challenge to Comparative Politics', West European Politics, 17:1 (1994), pp. 1-30, and Simon Hix, The Political System of the EU (New York: St. Martin's Press, 1999). His point was not to disregard comparative analysis, claiming that EU was to be compared with other polities rather than regions.

${ }^{51}$ See Ben Rosamond for a detailed discussion about the relationship between EU studies and international studies. Ben Rosamond, Theories of European Integration (Basingstoke: Macmillan, 2000); also see Alex Warleigh, 'In Defence of Intra-Disciplinarity. European Studies, the New Regionalism, and the Issue of Democratisation', Cambridge Review of International Affairs, 17:2 (2004), pp. 301-18; Alex Warleigh, 'Learning form Europe? EU Studies and the Re-thinking of International Relations', European Journal of International Relations, 12:1 (2006), pp. 31-51.

52 Ben Rosamond, 'Rethinking Classical Integration Theory', in Andrew F. Cooper, Christopher W. Hughes and Philippe De Lombaerde (eds), Regionalisation and Global Governance. The Taming of Globalisation (Abingdon and New York: Routledge, 2008), pp. 80-95. 
specialisation and comparative analysis. ${ }^{53}$ Until recently the former has been predominant, resulting in an overemphasis on case study methods. The case study method has the obvious advantage that the context and the specifics and nuances of each regionalisation process can be more easily grasped. The method allows for 'within-case' analysis and process tracking, which is particularly relevant to the study of regionalisation and the adjustment of actors to institutional changes. Regional and area specialists are certainly correct in asserting that we need deep multidisciplinary knowledge of various contexts and people. The disadvantage of case studies is, however, that a single case is a weak base for creating new generalisations or invalidating existing generalisations. ${ }^{54}$ Hence, comparative analysis helps to avoid ethnocentric bias and culture-bound interpretations that can arise, when a specialisation is over-contextualised or the area of study is too isolated.

This preference for the case-study method should not only be explained in terms of the (complex) characteristics of the phenomenon under study, but also in terms of the disciplinary traditions and practices in International Relations. Compared to Economics, for example, there is, generally speaking, less rigor in empirical 'testing' of hypotheses using data and standardised techniques. ${ }^{55}$

A sociological explanation for the single case approach (focusing on the European case or other cases) is that the majority of scholars have historically tended to specialise in a particular region - regardless of what discipline they come from (Comparative Politics, International Relations, Area Studies). Sometimes comparisons are made within each region (intra-regional comparison, for instance, comparing the different regionalisms in Asia), and a small but increasing number of scholars compare across regions as well (cross-regional comparison). The fundamental problem therein is that many case studies and the vast majority of comparisons tend to use theoretical frameworks that are biased towards European integration theory and practice.

The above-mentioned combination of complexity and a (perceived) lack of comparable cases in regional studies is an example of the problem known in the literature as the many variables/small-N problem, which makes it complicated to reach strong conclusions about the relationships between variables with a sufficient degree of confidence. The recommended research strategies in these situations point to the need to increase the number of cases (if possible), to allow for across-case comparisons, and to concentrate on a limited number of variables, controlling for a number of excluded variables. ${ }^{56}$

53 Fredrik Söderbaum, 'Comparative Regional Integration and Regionalism', in Todd Landman and Neil Robinson (eds), Handbook of Comparative Politics (London: Sage, 2009).

${ }^{54}$ Walter A. Axline, 'Comparative Case Studies of Regional Cooperation Among Developing Countries', in Walter A. Axline (ed.), The Political Economy of Regional Cooperation. Comparative Case Studies (London: Pinter Publishers, 1994), p. 15.

55 Barry Eichengreen, 'Dental Hygiene and Nuclear War: How International Relations Looks from Economics', International Organization, 52:4 (1998), pp. 993-1012.

56 David Silverman, Doing Qualitative Research (London: Sage Publications, 2000), p. 179; Jack S. Levy, 'Qualitative Methods in International Relations', in Michael Brecher and Frank P. Harvey (eds), Evaluating Methodology in International Studies (Ann Arbor: The University of Michigan Press, 2002), pp. 140-41; Zeev Maoz, 'Case Study Methodology in International Studies. From Storytelling to Hypothesis Testing', in Michael Brecher and Frank P. Harvey (eds), Evaluating Methodology in International Studies (Ann Arbor: The University of Michigan Press, 2002), p. 163. 
With respect to the first point, it is important to distinguish between regions and regional organisations as 'cases', and what constitutes a 'case', from the perspective of the empirical research set-up. One particular region or regional organisation can easily deliver (or be disaggregated into) several 'cases', depending on the research questions that are addressed. ${ }^{57}$ The consideration of different moments or lapses in time, if it makes sense, is only one strategy that can be followed here to multiply the number of cases. Cases should not therefore be equated with observations. One case will often allow for different observations to be made, so that minimal sample sizes can be reached to perform sensible quantitative analyses.

With respect to case selection, it should be based on relevance and the objective of the research project ('purposive' case selection), or it may be theoretically framed ('theoretical' sampling). ${ }^{58}$ In our opinion, case selection in comparative regionalism deserves more attention from researchers. Many comparisons tend to be based on accidental circumstances and opportunities of individual researchers or availability of data as well as the view that intergovernmental regional organisations or regional trading schemes are comparable across-the-board (without much discussion whether these are comparable or not). In our view, case selection should be more closely connected to the research problem and the chosen conceptual and theoretical framework being employed. As explained before, conceptual clarity makes the identification of suitable cases for comparison easier. An interesting avenue for identifying relevant comparators is also to use emerging or existing interregional interactions as indicators of commonality between regions. This is based on the assumption that regions (just like states) will interact when they have something in common (competences, interests, scale, etc.) and, in this way, the comparators are endogenously defined by the regions themselves. In addition, this strategy can contribute to the policy-relevance of the research work.

An alternative approach to case selection is to use preliminary quantitative analysis to guide the process, by focusing on the core cases and/or by focusing on outliers. A promising line of enquiry is to use mixed methods (that is, to combine, within the same research project or programme, qualitative and quantitative approaches in order to generate synergies), like in Lieberman's proposal for 'nested analysis'. ${ }^{59}$ However, it should be observed that the use of mixed methods necessitates the use of research projects of a minimum scale, possibly going beyond the average scale of individual (comparative) research endeavours.

Applied to the EU this means that as an object of research the EU can be studied in different ways and its comparability depends on the issue studied. As all other aspects of the social realm the EU has at the same time highly individual

${ }^{57}$ See also, Gary King, Robert Keohane and Sidney Verba, Designing Social Inquiry: Scientific Inference in Qualitative Research (Princeton NJ: Princeton University Press, 1994).

${ }^{58}$ Silverman, ibid., pp. 104-6; Jack S. Levy, 'Qualitative Methods in International Relations', in Michael Brecher and Frank P. Harvey (eds), Evaluating Methodology in International Studies (Ann Arbor: The University of Michigan Press, 2002); Zeev Maoz, 'Case Study Methodology in International Studies. From Storytelling to Hypothesis Testing', in Michael Brecher and Frank P. Harvey (eds), Evaluating Methodology in International Studies (Ann Arbor: The University of Michigan Press, 2002), p. 166; Kathleen M. Eisenhardt, 'Building Theories from Case Study Research', in A. Michael Huberman and Matthew B. Miles (eds), The Qualitative Researcher's Companion (Thousand Oakes: Sage Publications, 2002), pp. 12-3.

${ }^{59}$ Evan S. Lieberman, 'Nested Analysis as a Mixed-Method Strategy for Comparative Research', American Political Science Review, 99:3 (2005), pp. 435-52. 
features and general characteristics it shares with other regional entities. As such, one can claim that in some aspects the EU can be compared with many other forms of regionalism. For instance, one way to look at the EU as being one amongst many regional trade agreements notified at the WTO. But simultaneously, the EU can only be compared with a small number of other regional organisations. And finally, the EU has indeed also some unique properties. This is the case for at least one issue: the EU is the first and only international organisation that gives citizenship to the citizens of its member states. ${ }^{60}$ So the EU is in some cases like all other regional organisations, in other cases like some other regional organisations and in certain ways like no other regional organisations.

We are thus of the view that the comparative element in regionalisation studies should be further developed along different tracks as it will be crucial for enhancing communication between various theoretical standpoints and regional specialisations. As noted above, while doing comparative research, it is crucial to move beyond the 'false universalism' inherent in a selective reading of regionalism in the core, and in the EU in particular. As Hurrell asserts, rather than trying to understand other regions through the distorting mirror of Europe, it is better to think in general theoretical terms and in ways that draw both on traditional international relations theory, comparative politics and on other areas of social thought. ${ }^{61}$ This will only be possible if the case of Europe is integrated within a larger and more general discourse of comparative regionalism, built around general concepts and theories, but which it the same time remains culturally sensitive.

This calls for a middle ground to be established between context and area studies on the one hand, and 'hard' social science as reflected in the use of 'laborative' comparisons on the other. This middle ground has been referred to as the 'eclectic center' of comparative studies. ${ }^{62}$ Such a middle ground can avoid the problem of exaggerated contextualisation on the one hand, and over-generalised (or irrelevant) theory, on the other. Achieving this perspective on the eclectic centre of comparative studies will be inclusive rather than exclusive - even if it will be too 'social science-y' for some and too much of 'storytelling' for others. ${ }^{63}$ There need not be any opposition between area studies and disciplinary studies/international studies, or between particularising and universalising studies. The eclectic centre perspective should enable Area Studies, Comparative Politics and International Studies to engage in a more fruitful dialogue, and through that process overcome the fragmentation in the field of regionalism and regional integration. Such perspective should be able to bridge divisions between earlier and more recent theories and experiences of regionalism and regional integration. It should also enable cross-fertilisation between different regional debates and specialisations.

${ }^{60}$ Jaap A. Hoeksma, 'Voorbij Federatie en Confederatie: De EU als unie van burgers en lidstaten', Internationale Spectator, 63:2 (2009), p. 84.

${ }^{61}$ Andrew Hurrell, 'The Regional Dimension of International Relations Theory', in Mary Farrell, Björn Hettne and Luk Van Langenhove (eds), The Global Politics of Regionalism. Theory and Practice (London: Pluto Press, 2005), p. 39.

${ }^{62}$ Atul Kohli, Peter B. Evans, Peter J. Katzenstein et al., 'The Role of Theory in Comparative Politics. A Symposium', World Politics, 48:1 (1995), pp. 1-49; also see Africa Today, special issue, 44:2 (1997); Andrew W. Axline (ed.), The Political Economy of Regional Cooperation. Comparative Case Studies (London: Pinter Publishers, 1994); Anthony Payne, 'The New Political Economy of Area Studies', Millennium: Journal of International Studies, $27: 2$ (1998), pp. 253-73.

63 Atul Kohli, Peter B. Evans, Peter J. Katzenstein et al., 'The Role of Theory in Comparative Politics. A Symposium', World Politics, 48:1 (1995), pp. 1-49. 
Finally, an eclectic centre perspective will highlight the richness of comparative analysis, and enhance a dialogue about the fundamentals of comparative analysis (for example, what constitutes comparable cases, and the many different forms, methods and design of comparative analysis).

\section{Stylised facts and the role of quantitative research}

In the previous sections we discussed the prevailing preference for case study methods and regional specialisation. Although we recognise the obvious advantages of this method, we argue here that regionalisation scholars could benefit from a more open attitude towards adopting different empirical research methods, including quantitative methods, and thus striking a better balance between qualitative and quantitative techniques when studying regions. Quantitative research serves thereby not only the purpose of empirical verification/falsification of research hypotheses but generates interesting feed-back effects for the methodological, conceptual and theoretical discussions. Theorising about regionalism is all too often based on the a-critical use of a number of 'stylised facts', referring to the relative success or depth of certain regional integration processes or organisations compared to others. Let us illustrate the potential of paying more attention to quantitative analysis in regionalisation studies with a few examples.

\section{Intra-regional trade indicators}

Political scientists and economists alike often refer to the intra-regional trade share, defined as intra-regional trade as a percentage of total trade by member states of an integration scheme. The indicator is often a-critically used as an indicator of 'success' of a particular integration project, but at the same time, although a bit confusingly, also as an indicator of the appropriateness of the conditions to engage in further steps in the integration process. In The Choice for Europe, Moravcsik suggested that regional trade dependency, captured by such indicators, is in effect the main underlying factor explaining the demand for (more) integration in a particular region. ${ }^{64}$

One of the stylised facts surrounding integration studies is precisely that the EU shows a high value for this indicator, whereas other regions do not. Whereas the EU-27 scores around 70 per cent on this indicator, regional arrangements like the Caribbean Community Secretariat (CARICOM) or the South African Development Community (SADC) score below 10 per cent. ${ }^{65}$ A lot of theorising is explicitly or implicitly based on this 'stylised fact'. However, the indicator is not unproblematic. One of the reasons for this is that the indicator is correlated with the size of the region; large (small) economic regions logically trade more (less)

\footnotetext{
${ }^{64}$ Andrew Moravcsik, The Choice of Europe. Social Purpose and State Power from Messina to Maastricht (Ithaca: Cornell University Press, 1998).

65 Data obtained from the Regional Integration Knowledge System (RIKS), \{http://www.riks.garneteu.org/ $\}$ last accessed on 18 April 2008.
} 
within their region and less (more) with the rest of the world. There is thus a problem of comparability, especially if we want the indicator to reflect the 'success' of regional integration policies. Alternative measures, correcting the intra-regional trade share for the scale bias and other technical deficiencies have been proposed. ${ }^{66}$ Without going into a detailed discussion of all these indicators here, we just signal that different indicators (all reflecting the importance of intra-regional trade) can produce different country rankings (see Table 1). The interesting observation here is that precisely by making the indicators 'more comparable', the generally accepted stylised facts start to lose their solidity.

\begin{tabular}{llll}
\hline $\begin{array}{c}\text { Ranking according } \\
\text { to: }\end{array}$ & $\begin{array}{c}\text { Intra-regional trade } \\
\text { share }\end{array}$ & $\begin{array}{c}\text { Intra-regional trade } \\
\text { intensity index }\end{array}$ & $\begin{array}{c}\text { Symmetric trade } \\
\text { introversion index }\end{array}$ \\
\hline 1 & EU-27 & CARICOM & CARICOM \\
2 & EU-15 & CAN & CAN \\
3 & NAFTA & SADC & NAFTA \\
4 & ASEAN & MERCOSUR & SADC \\
5 & MERCOSUR & ASEAN & EU-27 \\
6 & CAN & NAFTA & MERCOSUR \\
8 & CARICOM & EU-27 & EU-15 \\
\hline
\end{tabular}

Table 1. Ranking of regional integration groupings according to different indicators relating to the importance of intra-regional trade $e^{67}$

\section{Regional budgets}

In his 1968 article, Nye proposed to use two indicators (and a third being related to the second) to compare regional integration processes in different regions more systematically and more 'scientifically'. The first was the indicator of intra-regional trade (exports), which has been discussed in the previous paragraphs. The second was an indicator which he called 'services integration'. However, that basically reflected the budgets available at the regional level for the financing of regional policies and institutions. And whereas the first has been widely used since then, the second has not been used at all, although it reflects an important dimension of a regionalisation process: the mobilisation (or not) of public funds at the regional level. Indicators capturing this dimension inform us not only of the budgetary space which is available for regional policy initiatives, but they are good indicators of the 'depth' of the process (otherwise often an unclear concept) or the level of commitment of the participating states, and could be used to test hypotheses about the sustainability or effects of the processes.

Qualitative comparative research is now often based on the observation of the formal characteristics (and coincidences/divergences) of the integration processes

${ }^{66}$ Lelio Iapadre, 'Regional Integration and the Geography of World Trade. Statistical Indicators and Empirical Evidence', in Philippe De Lombaerde (ed.), Assessment and Measurement of Regional Integration (London: Routledge. 2006), pp. 66-85.

${ }^{67}$ Source: RIKS, \{http://www.riks.garnet-eu.org/\} last accessed on 18 April 2008. 
and institutions. Observed differences in terms of effectiveness, effects or sustainability are then explained in terms of different combinations of supply/demand factors for integration or other contextual factors but, in our opinion, taking data on budgets (and related figures) into account has the potential to enrich the analysis.

As an illustration, many observers have pointed to the African Union and the Andean Community (CAN) as examples of regional organisations that have 'copied', at least to some extent, the institutions of the EU. They then proceed to observe that that these organisations are less efficient and less effective than the EU, thus presenting a new 'stylised fact' on the basis of which new theorising is based. However, the superficial character of this comparison is obvious when it is taken into account that the budget of CAN should be multiplied by 400 to be 'comparable' to the European budget (as a percentage of Gross Domestic Product (GDP)), and that the budget of the African Union should even be multiplied by $10000 !^{68}$ In Nye's article the budget of the Central American Common Market (CAMC) had to be multiplied by 80 to reach the level of the East African Common Market (EACM) (see Table 2). Not relating the outcomes of integration policies to resources does not enable firm conclusions about efficiency or effectiveness of regional organisations to be drawn. ${ }^{69}$

\begin{tabular}{lccc}
\hline \multicolumn{1}{c}{ Regions } & EIt & EIs & Percent of EIs externally financed \\
\hline EACM & 25 & 8.0 & 16 \\
CACM & 19 & 0.1 & 46 \\
\hline
\end{tabular}

Table 2. 'Trade and Services Integration' in the East African Common Market and the Central American Common Market, $1965^{70}$

\section{Regional integration scores}

A third example refers to the attempts that have been made to attribute scores to different integration processes in order to 'measure' and compare their depths and speeds. ${ }^{71}$ Without going into the details of each of these studies, the results again reveal a number of interesting points. In Table 3, for example, rankings are shown

${ }^{68}$ Data gathered by the authors.

69 Budgetary data can further be used to derive (comparative) fiscal integration indicators, in an analogous way as those developed to study decentralisation processes. Philippe De Lombaerde, and Ana-Cristina Costea, 'Comparative Fiscal Integration Indicators', in Philippe De Lombaerde (ed.), Assessment and Measurement of Regional Integration (London: Routledge, 2006), pp. 130-45.

${ }^{70} \mathrm{EIt}=$ trade integration $=$ proportion of intraregional exports to the total exports of the region. EIs $=$ services integration $=$ expenditures on jointly administrated services (including the administration of trade integration schemes) as a per cent of GNP. Source: Joseph S. Nye, 'Comparative Regional Integration. Concept and Measurement', International Organization, 22:4 (1968), pp. 861-2.

${ }^{71}$ Such attempts include G. C. Hufbauer and J. J. Schott, Western Hemisphere Economic Integration (Washington: Institute for International Economics, 1994); Ettore Dorrucci, Stefano Firpo, Marcel Fratzscher and Francesco Paolo Mongelli, 'The Link between Institutional and Economic Integration: Insights for Latin America from the European Experience', Open Economies Review, 15:3 (2004), pp. 239-60; Gaspare M. Genna and Yi Feng, 'Regional Integration and Domestic Institutional Homogeneity: A Comparative Analysis of Regional Integration in the Americas, Pacific Asia and Western Europe', Review of International Political Economy, 10:2 (2003), pp. 278-309. Most of these attempts used the Balassa framework. B. Balassa, The Theory of Economic Integration (Homewood, IL.: Irwin, 1961). 
for five integration arrangements in the Americas, referring to approximately the same 'moment' in time and using the same conceptual framework (Balassa framework). The rankings are different, pointing again to the need to question the robustness of certain widely shared stylised facts (for example, Mercosur as the most successful integration scheme outside Europe, the low level of institutionalised integration in North American Free Trade Agreement, etc.).

\begin{tabular}{ll}
\hline \multicolumn{1}{c}{ Dorrucci et al. $(2002,2004)$} & \multicolumn{1}{c}{ Feng and Genna $(2003,2004,2005)$} \\
\hline CARICOM & CAN \\
CAN & CARICOM \\
CACM & NAFTA \\
Mercosur & Mercosur \\
NAFTA & CACM \\
\hline
\end{tabular}

Table 3. Inconsistencies between (institutional) integration score-based rankings in the Americas $^{72}$

Coding exercises also force one to question the sequencing of integration phases in the real world. And the need to make weights explicit forces one to reflect upon the relative importance of different means of integration and on the meaning of words like 'deep' integration.

\section{Conclusion}

Over the last decade regionalism has become somewhat of an academic growth industry in a number of social science specialisations: European studies, comparative politics, international economics, international geography, international relations and international political economy. The approach of these different academic specialisations varies considerably, which means that regionalism means different things to different people. This fragmentation has resulted in that the comparative element in the study of regionalism remains underdeveloped. Disagreements over what to compare, how to compare and sometimes even why to compare at all, arise predominantly as a consequence of at least three general problems and divisions in the field: (i) the lack of debate between those from EU studies and those interested in regionalism in the rest of the world; (ii) the lack of communication between scholars from various theoretical standpoints and research traditions (especially between rationalists and reflectivists), and (iii) the tension between regional specialisation and idiographic analysis (case and area studies) and more comparative and nomothetic analysis.

\footnotetext{
72 Note: regional arrangements are ranked from high to low levels of institutional integration. Feng and Genna use the term integration achievement but it is equivalent to institutional integration. Source: Philippe De Lombaerde, Ettore Dorrucci, Gaspare M. Genna et al., 'Quantitative Monitoring and Comparison of Regional Integration Processes: Steps Towards Good Practise', in Ariane Kösler and Martin Zimmek (eds), Elements of Regional Integration (Baden-Baden: Nomos. 2008), pp. 149-79.
} 
In many ways these divisions are related. In particular, the rationalist and Europe-centred theories may have comparative ambitions, but reflectivists and specialists of non-European regions tend to emphasise the irrelevance of such theories in their particular regional contexts, which only reinforces the divides and lack of communication in the research field. The general argument of this article is that the ongoing development of comparative regionalism requires a more constructive dialogue between these standpoints. The way forward is demanding. Constructive dialogue and cumulative research imply less 'hegemonic attempts' and less ignorance. The tensions and differences in the field illustrate the fact that the regional phenomenon is multidimensional and pluralist, which seems to imply that there is need for a certain degree of analytical and theoretical eclecticism at the same time as we need greater clarity. As outlined in this article, the ingredients of 'better' comparative research may include: more conceptual clarity (and flexibility, at the same time), sounder case selection when cases are compared, allowing for heterogeneous or asymmetric comparisons when appropriate (involving microregions and/or states), a better integration of qualitative and quantitative methods, and a more careful use and interpretation of stylised facts. 